\title{
Pasemah Visual Arts: Diversity of Shapes and Postures of Statues
}

\author{
A. Erwan Suryanegara \\ Faculty of Art and Design \\ Doctoral Programme, Bandung Institute of Technology \\ erwan_suryanegara@yahoo.com
}

\author{
Agus Sachari \\ Tjetjep Rohendi Rohidi \\ Industrial Design, Faculty of Art and Desain \\ Bandung Institute of Technology \\ University State of Semarang
}

\begin{abstract}
Nusantara (Archipelago) is Indonesia's a cluster of islands. In one of the islands, Sumatra, there is a range of mounts stretching from north to south, called Bukit Barisan (mountains range). Moreover, in the Bukit Barisan there is a region named Pasemah. Geographically, the topography of the region consists of mountains, ripples, and plateaus. It has long been called Pasemah Plateau, a considerably wide area encompassing three provinces: Bengkulu, South Sumatra, and Lampung. There are lots of archeological monuments as ancient remains in forms the artifacts of megalithic tradition spreading widely in the mountains. Pasemah statues are made of frozen rocks monolithic-andesitic medium. The megalithic artifacts discovered are of varying types. Based on a field study conducted, most of the megalithic remains in Pasemah either fall into a category of fine arts. The ancient artifacts have been discovered since the era of East Indie up to now, but they have been seen more from an archeological viewpoint. Thus far there is no specialized and deep study of the artifacts like one that the writer conducted in the present research by using a visual artsstudy. By drawing on archeological library data, the present research would carry out a field study, in order to obtain primary data that is suitable with a study of fine arts, so that anything related to the existence of the statues which are the ancient products of fine arts, particularly statues' shapes and postures, could be discovered.
\end{abstract}

Keywords: Pasemah, statue, megalithic, shape, posture

\section{INTRODUCTION}

Nusantara has many invaluable potentials, one of which being cultural diversity due to its geographical condition which consists of islands. The cluster of Nusantara islands is located between two continents, two oceans, and passed through by equatorial line. Sumatra Island is located in the far west of Nusantara, where Bukit Barisan stretches from north to south. A region in southern Bukit Barisan includes more or less Jambi, Bengkulu, South Sumatra, and Lampung. Lots of ancient remains in forms of monolith stones, well known as Megalithic Tradition, are found there. According to Franz Dahler in the prolog of his book Origin and End of Human Beings (2001): "interesting from the presentation of data on ancient humans is that, in fact, Indonesia takes a great part." As seen on fig. 1 below, in Nusantara there are indeed found numerous prehistoric remains, particularly from Stone Age.

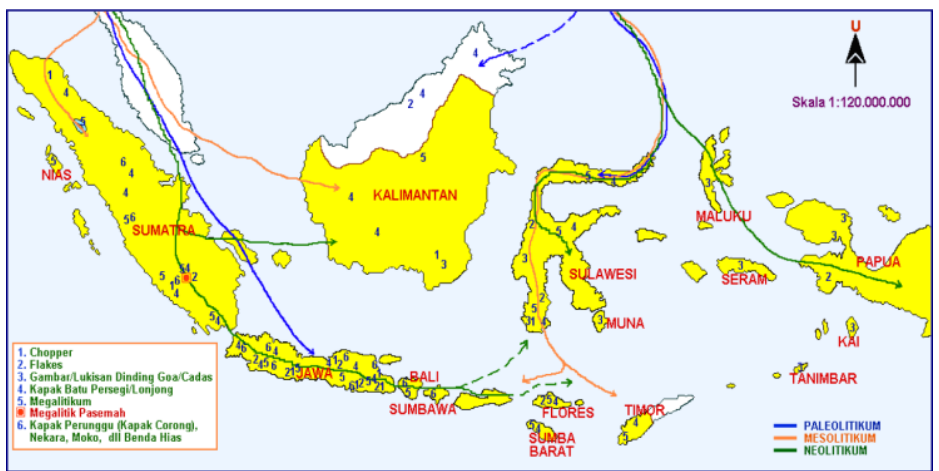

Fig1. Map of the Location of the spreading of prehistoric artifacts and humans in Nusantara.

Source: Adapted from the books of Bagyo Prasetyo et. al. and R. Soekmono, Imam Suhardiman's atlas, and the writer: 2005/2006 


\section{A. Erwan Suryanegara et al.}

In prehistoric civilization, human beings have not been acquainted with a written language and thus they inclined to communicate to one another by oral and visual. Experts group the era into four cultural periods. For example, R. Soekmono (1976) suggests four stages of cultures, namely: "Old Stone Culture (Paleoliticum), Middle Stone Culture (Mesoliticum), New Stone Culture (neoliticum), and Metal Culture." The range of prehistoric period is much longer than that of historical period, and their occurrences in prehistoric ages and their transformations into historic era are not in coincidence one another in some areas.

From the four stages of cultural developments, in what era was megalithic tradition occurring? Why do experts call it megalithic tradition instead of megalithic culture? Megalithic tradition was proceeding from generation to generation in various areas. According to Bagyo Prasetyo (2015:35), "Except in Australia, traditional megalithic remains are found almost evenly in diverse hemispheres, while Old Stone, Middle Stone, and Metal cultures inclined to evenly spread to various hemispheres." Megalithic tradition was proceeding when human beings had been acquainted with metal tools, and even in particular places with some adjustments still proceeding till now.

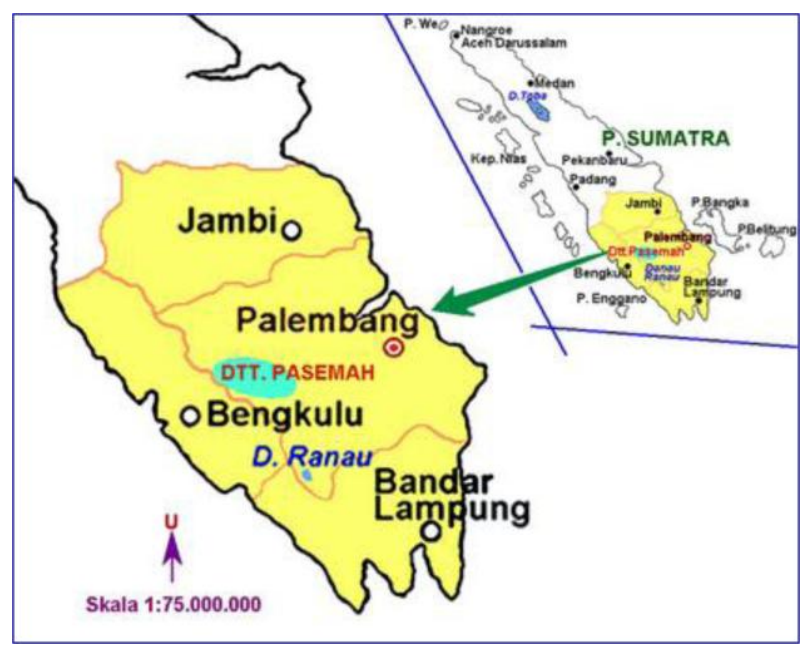

Fig2. Map of Batang Hari Sembilan Culture Region.

Source: The Writer, 2005/2006

The regions of Bengkulu, South Sumatra, and Lampung as the locations where the megalithic remains had been recovered are indeed called later as Batanghari Sembilan cultural region, as shown on fig. 2, including: Jambi, Bengkulu, South Sumatra, and Lampung. A research by Van der Hoop in Pasemah Plateau has defied previous speculative arguments saying that the megalithic artifacts in Pasemah Plateau were the cultural remains of Hindu. Hoop (1932:156) refused and convincingly argued that the artifacts are the remains of megalithic traditions because the statues show no Hinduism signs. Since then, the artifacts have been constantly an object of discussion and research by experts. After independence, archeological studies in Pasemah region have been continued by Palembang Archeology Center together with National Archeology Center.

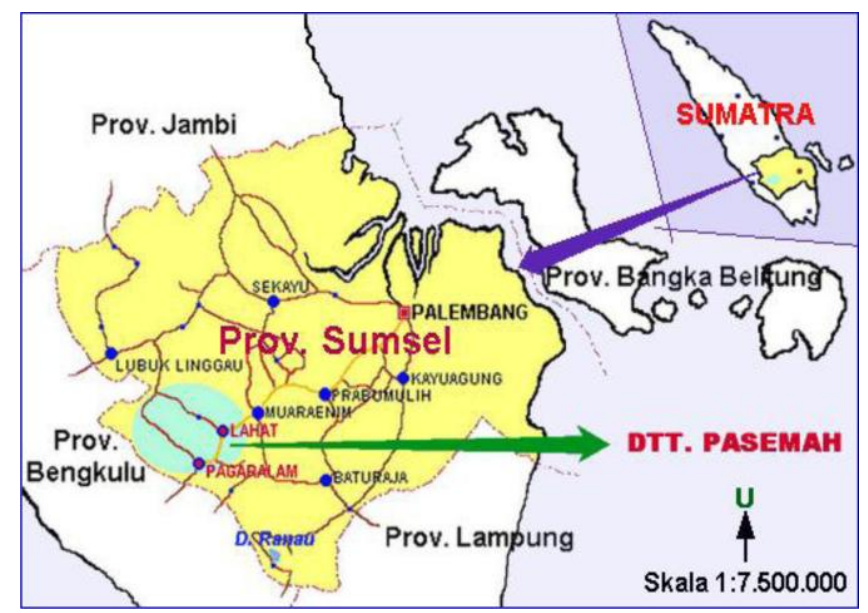

Fig3. Map of the locations of Pasemah DTT in South Sumatra Province.

Source: The Writer, 2005/2006 
To the south of the stretch of the Bukit Barisan there is a region named Pasemah Plateau, more precisely in Lahat Regency and Pagaralam Municipality, South Sumatra Province, where most remains of the artifacts from Megalithic Tradition of prehistoric Nusantara were discovered, as the results of previous archeological researches. In fact, these artifacts are spreading in Bengkulu, South Sumatra, and Lampung. However, the remains are found mostly in South Sumatra area and thus it is reasonably hailed as the Center of Megalithic (Fig. 3), "because," as suggested by Ayu Kusumawati and Haris Sukendar (2003:16), "the area comes out as a center of megalithic." In Lahat and Pagaralan, there are 22 sites, as seen in the data from Palembang Archeology Center described by Budi Wiyana (1996). Meanwhile, according to Samsudin et al. (2013) there are 27 sites. However, all of them are also in agreement with the research by Van derajat Hoop (1930-31), later translated and published by a title of Megalithic Remains in South Sumatra, 1932.

F. Wagner, also in agreement with Soejono (in Kritantina Kusumawati, 2015), stated that "megalithic concept actually not only refers to large stones, because small stones and even ones without document can be said megalithic, as long as they are intended particularly as a place (temple) of sacrifice for the spirits of ancestors." Moreover, in Nusantara, indigenous religions have existed for long times or since early prehistory. This is in agreement with the suggestions of many experts, including Rachmat Subagya (1981), Bagyo Prasetyo et al. (2004), and Ketut Wiradnyana (2015). Meanwhile, according to EB. Tylor, the indegious religions are "animism", whereas JG. Frazer calls it "magic", as stated in Daniel L. Pals's Seven Theories of Religion (translated, second edition, 2012).

Since popularized by Van der Hoop (1930-1931), the artifacts of Pasemah megalithic traditions are of greatest variations, till now still studied continuously by archeologists. For example, a depiction of human and animal objects on Pasemah statues by seeing their relation with the paintings on stone tomb wall has been conducted by Bambang Sugianto (2000). Kritantina Indriastuti (2011) observed both styles and values of the stone reliefs of Pasemah megalithic statues. As Bagyo Prasetyo and Nurhadi Rangkuti (2015:23) expressed, discussing the megalithic phenomena in Nusantara with their diverse complexities is apparently endless. This is reasonably admitted given the wide areas of the spreading and diversity of megalithic artifacts found in Nusantara, including on course ones found in Pasemah Plateau. Accordingly, the writer investigated it from a visual artsviewpoint.

From a literature study, among others Pustaka Wisata Budaya Megalitik Bumi Pasemah (Megalithic Cultural Tour Book of Pasemah Land) by Ayu Kusumawati and Haris Sukendar (2003), the shapes of "menhir statues" or totems existing in many areas haven't been complete yet as compared to that of Pasemah megalithic statues. And a personal field study in 2006 where the writer adopted a visual artsviewpoint in studying the artifacts resulted in new readings, one of which described here was that Pasemah statues didn't recognize repetition of shapes and postures. Besides, there are still the results of other characteristic readings according to art viewpoints, in this case fine arts. The initial study of visual artsshould be followed up as well as spread and implemented, so as to be beneficial particularly for visual artsworld, the communities around the culture areas (sites), and general public. The objective of the present research was to complete the history of initial presence and the diversity of the shapes of fine art works in Nusantara.

\section{Methodology}

In agreement with the result of literature study suggesting that many Pasemah megalithic remains are found in Bengkulu, South Sumatra (Lahat and Pagaralam), and Lampung, it was confirmed that most of them are indeed discovered in Lahat and Pagaralam. The megalithic monumental artifacts existing in Pasemah Plateau still generally can be found directly in the field because they are generally still at their original sites.

In nearly every site in Pasemah there are megalithic statues. These statues of varied shapes and postures always appear together with other megalithic artifacts at a site, which are visual works of the past the existence of which is, besides from being a monument of existence (power), as a medium of worshiping the spirits of those ancestor who have an inseparable relationship with their natural environment. Thus, the present research more appropriately used a field survey (personal observation), in addition to library study and interview with experts.

In the course of the field study, facts were obtained that, as monumental works, each Pasemah statue has its own distinct landscape. Completely reading directly in the field, both megalithic statue subjects and the views indicate inseparable relationship between their existence and their surrounding natural 


\section{A. Erwan Suryanegara et al.}

environment, would be as analytical knife, as shown on Fig. 4 below, when the writer observed carefully the landscape of nature around Geramat site.

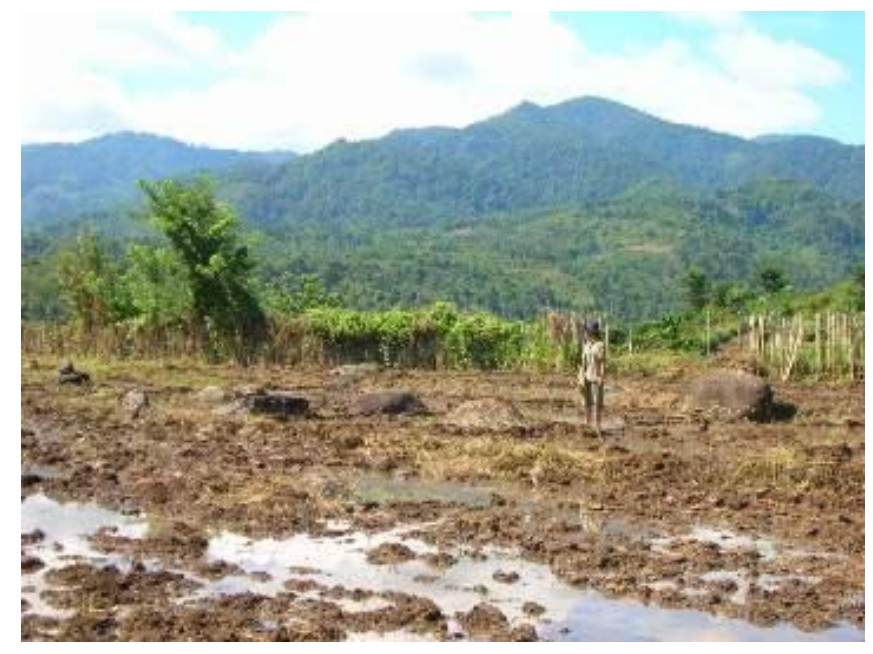

Fig4. A Site of Geramat, Lahat Regency.

Source: The Writer, 2005/2006

The personal observation method during the detailed field study of each Pasemah megalithic statue needed complete field data records in forms of photographs and audio visual. They were of high importance in enriching and sharpening the analytical process in detail, particularly during performing a visual study on the shape and posture of each of the statues showing that they are oriented to their surrounding natural environment. Of course, the data from library study and interviews with the experts on the monuments in Pasemah should always be attended.

Some other points that can be disclosed by personal observations in the investigated field at each megalithic site in Pasemah plateau are that the front and orientation of each statue artifact, site sketch, the pattern and position and the placement relation of each artifact at a site can be known. Fig, 5 below is a figure of sketch, pattern, and relation of artifacts at Pagaralam (Pagar Gunung) site - Lahat, as an example of the result of a study of personal observation in the field:

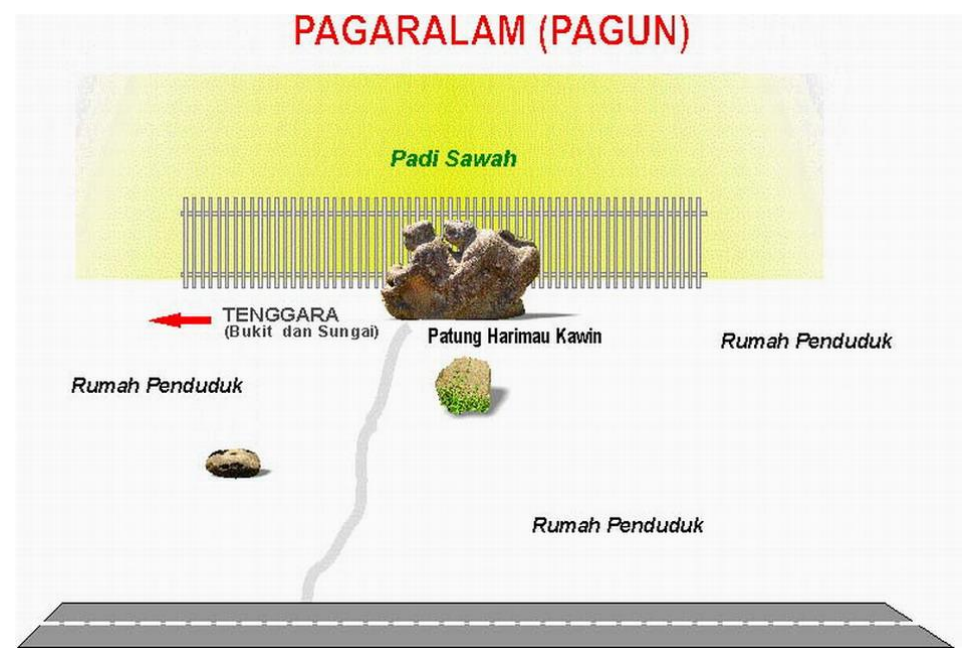

Fig5. A site of Pagun, in Lahat Regency.

Source: The Writer, 2005/2006

\section{RESULTS AND DISCUSSION}

By a library research concerning the four periods of prehistoric cultures as R. Soekmono (1976) suggests, it could be described the position of megalithic tradition in the four stages of human civilization (Diagram 1). From a field study by visiting the sites of megalithic remains one by one in Pasemah plateau, it could be known that not every site has statue artifacts, but that each Pasemah site has some types of megalithic artifacts, and that megalithic Pasemah site has a pattern of being always correlating with its surrounding natural environment condition, particularly in relation to the existence of a hill or mount, and can also be together with a source of waters such river or tebat (small lake). 


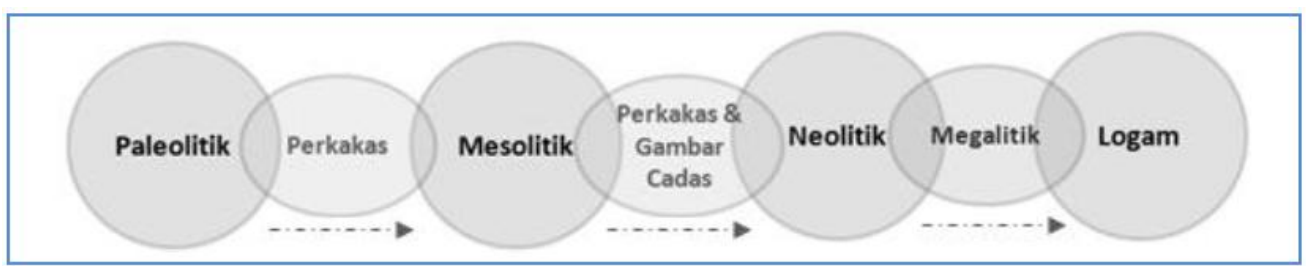

Diagram1. Megalithic Tradition of Early World Civilization.

Source: The Writer, 2015

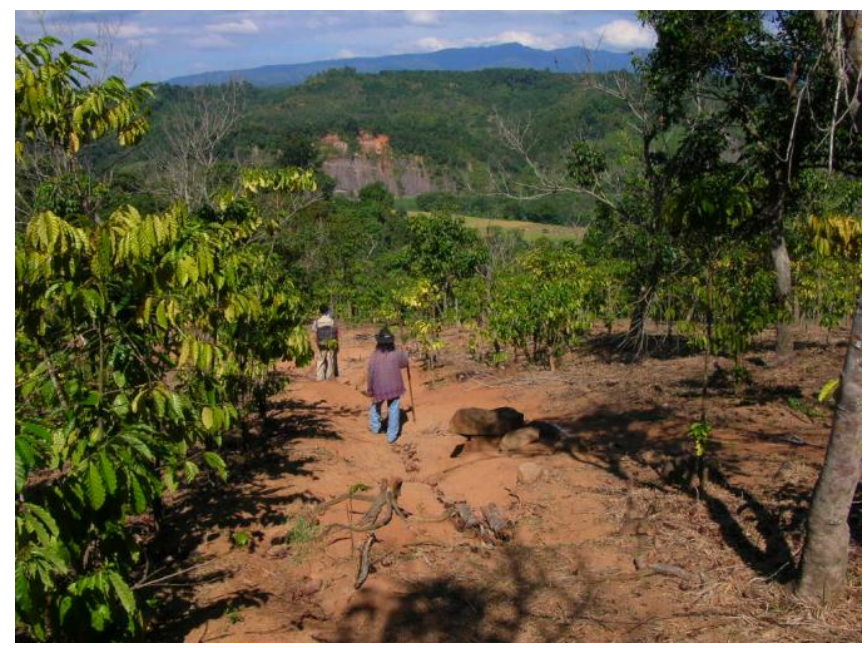

Fig6. Wavy Topography in Lahat Regency.

Source: The Writer, 2005/2006

A library study and a survey to both Lahat and Pagaralam revealed that the sites in Pasemah region are generally of wavy topography on Fig. 6. The writer has obtained convincing data that the characteristics of megalithic statues as found in Pasemah were not found in other contemporary areas, in Nusantara and even in the world. The megalithic statues in Pasemah plateau have as their objects either humans or animals, the bodies of which have been carved completely and variously, in a sense that there was no repetition at all as in totems or "menhir statue" as suggested by Haris Sukendar (1983) in Ayu and Haris Sukendar (2003). Pasemah statues are always different in visual, volume, shape, and dynamic posture because they generally demonstrate a moving gesture.

Lahat Regency and Pagaralam Municipality, South Sumatra, are indeed locations with the largest number of sites or megalithic sites compared to other areas in Bengkulu and in Lampung. This is in agreement with the results of previous researches learnt by a literature study. If we trace Bukit Barisan in southern Sumatra Island, we could find Pasemah megalithic sites spreading from Bengkulu, South Sumatra, to Lampung. In Lahat Regency and Pagaralam Municipality they are found in a largest number, as also suggested by Ayu and Haris Sukendar (2003).

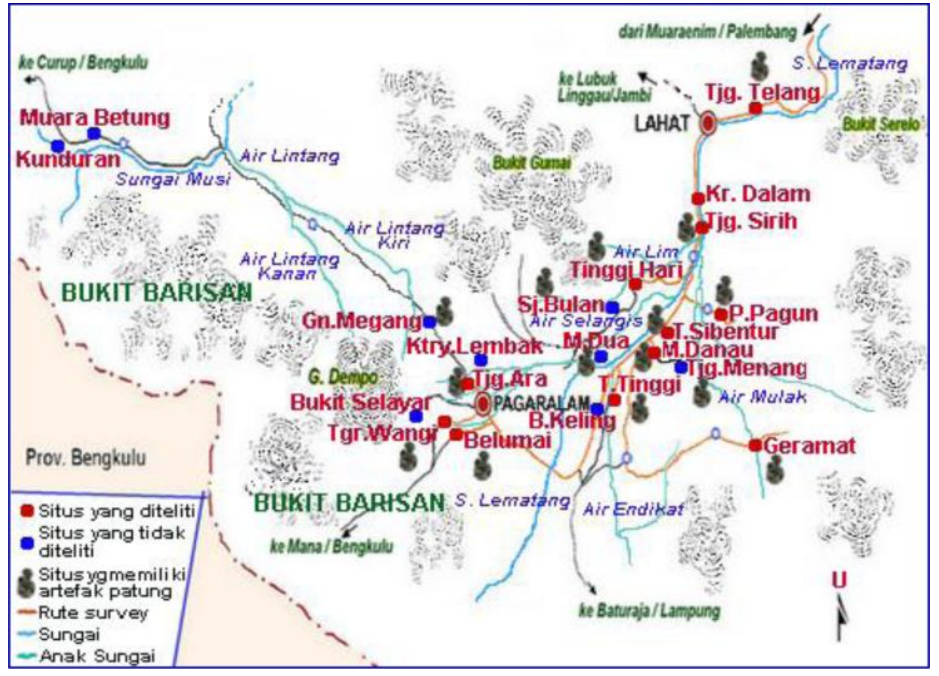

Fig7. Spreading Area of Sites in Pasemah.

Source: The Writer, 2005/2006 


\section{A. Erwan Suryanegara et al.}

Based on the results of a field study when visiting the existing sites one by one, spreading quite widely as shown on Fig. 7, 13 (thirteen) of the 22 (twenty two) Pasemah megalithic sites listed in Budi Winaya (1996). Another nine sites weren't surveyed because they have been represented by the visual works available in the other sites researched. In addition, there were indeed sites that have no visual work artifact, and four sites weren't discussed because their statue artifacts have been worn, but have been represented. From a field survey of the sites it was estimated that the number of sites may potentially still increase.

Geographically, the condition of Pasemah region is hilly and wavy and it is fertile with a green landscape of its tropical forest. Apparently it is one of the most important factors that supported the survival of the prehistoric humans. Bukit Barisan stretches along the west side of West Sumatra, in form of a range of green, hilly forests, and also a lofty, active volcano Mount Dempo. There is located Pasemah plateau, part of South Sumatra territory. Culturally, Pasemah region actually belongs to a cultural group named Batang Hari Sembilan (Nine Rivers) Culture.

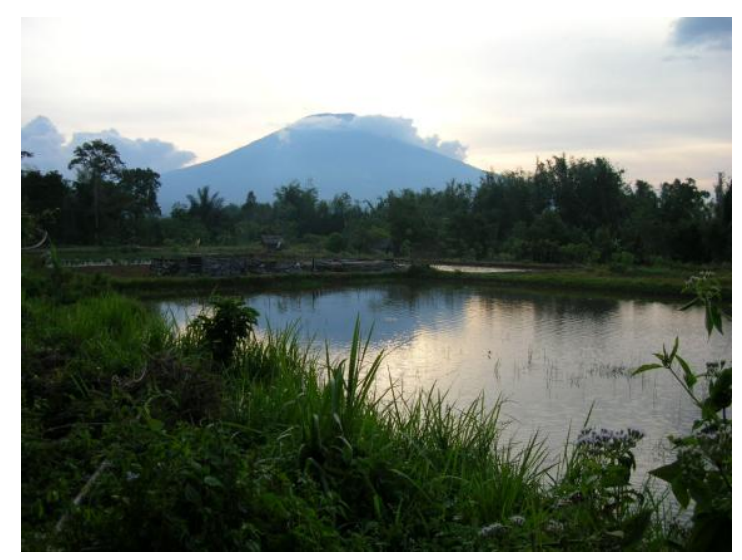

Fig8. Mount Dempo 3,159 ASL viewed from the site of Blumai - Pagaralam, South Sumatra.

\section{Source: The Writer, 2005/2006}

When the writer visited the field to collect data of ancient visual artifacts, it turned out that some changes were found between the time of Van derajat Hoop (1931), Budi Wiyana (1996), the writer (2005-2006), and Samsudin et al. (2013), e.g., changes in the names of sites, due to some changes in the names of villages where the sites were located. In addition, Lahat Regency is now politicaladministratively divided into two regencies, namely Lahat Regency and Pagaralam Municipality, and Pagaralam Municipality renamed itself to be Bumi Besemah, no longer Pasemah.

Table1. List of the Sites of Pasemah and Its Vicinity

\begin{tabular}{|l|l|l|c|}
\hline No. & Sites & Current Site Environment & Remarks \\
\hline 1. & Belumai I, & Water, wet field & Research location \\
& Belumai II, dan & Dry field & Research location \\
& Belumai III & Dry field & - \\
2. & Benua Keling & Hill, dry field & - \\
3. & Beringin Jaya & Village & Research location \\
4. & Bukit Selayar & Water, hill & Research location \\
5. & Geramat & Water, wet field & - \\
6. & Gunung Megang & Water, wet field, village & Research location \\
7. & Karang Dalam & Village, hill & - \\
8. & Kotaraya Lembak & Water, dry field & - \\
9. & Kunduran & Water, village & - \\
10. & Muara Betung & Water, hill, village & Research location \\
11. & Muara Danau & Dry field & - \\
12. & Muara Dua & Hill & Research location \\
13. & Pagaralam Pagun & Village, wet field & - \\
14. & Sinjar Bulan & Water, dry field, village & Research location \\
15. & Tanjung Ara & Wet field, village & - \\
16. & Tanjung Menang & Village & Research location \\
17. & Tanjung Sirih & Forest, hill, bushes, dry field & Research location \\
18. & Tanjung Telang & Dry field, hill, bushes, school & Research location \\
19. & Tebat Sibentur & Forest, bushes, dry field & \\
\hline
\end{tabular}




\begin{tabular}{|l|l|l|l|}
\hline \hline 20. & Tebing Tinggi & Water, wet field, dry field & Research location \\
21. & Tegur Wangi & Water, dry field & Research location \\
22. & Tinggi Hari I, & Hill, dry field, forest & Research location \\
& Tinggi Hari II, dan & Hill, dry field, forest & Research location \\
& Tinggi Hari III & Hill, dry field, forest & Research location \\
\hline
\end{tabular}

Source: Balar Palembang, 1996, and the writer, August 2005 - February 2006

The twenty two Pasemah megalithic sites in Table 1. above have now been divided into two parts, one part in administrative jurisdiction of Pagaralam Municipality (Blumai, Benua Keling, Beringinjaya, Bukit Selayar, Gunung Magang, Kotaraya Lambak, Tanjung Ara, Tegur Wangi) and another in administrative jurisdiction of Lahat Regency. Thus, when the writer collected the research data the writer should developed a coordination with the two local governments, though for the present research the writer consistently referred to a single character of cultural products, i.e., Pasemah plateau megalithic remains.

Based on the data obtained by both library study and field study, it was found that the types of megalithic visual works in Pasemah were: statue, painting, relief, and decorative motif. Particularly for decorative motif, as we know the prehistoric people had inclined to be mystical-religious. However, in fact, according to the results of the field study of the artifacts, it turned out that they also had have a motivation to decorate, as shown by the following menhir artifact where tumpal was carved repetitively at the upper side.

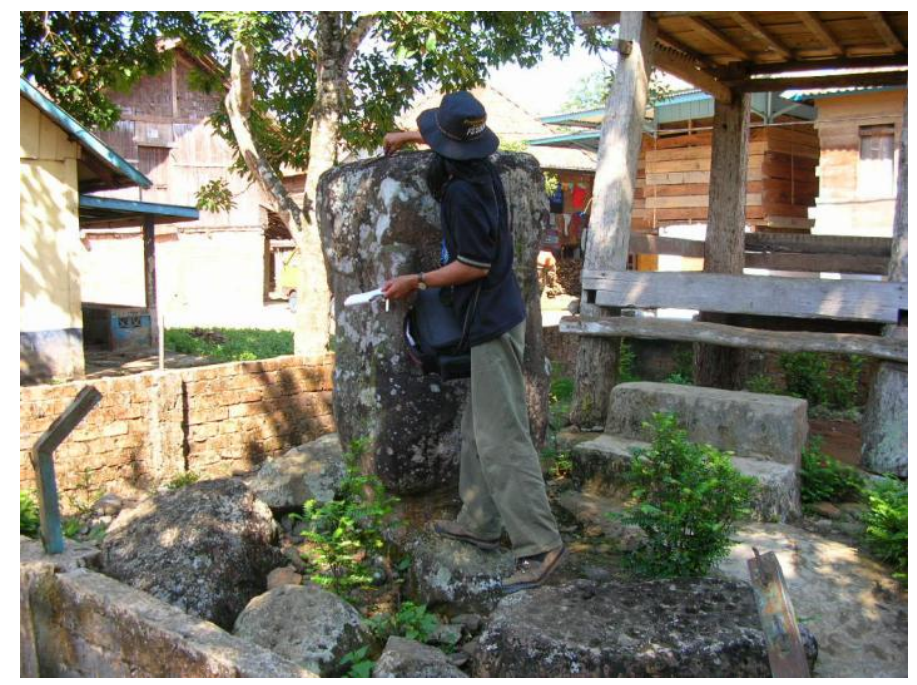

Fig9. A triangle (tumpal) symbol in Menhir, Karang Dalam site.

Source: The Writer, 2005/2006

Though they were a mystical community, it turned out that the menhir in Karang Dalam was of triangle shape, understood as one of the ancient geometric symbols called tumpal, has been carved at the upper side of menhir and carved repetitively, impressing as if it played a role as a decoration (decorative motif) at the menhir. The types of visual works in forms of painting, relief, and decorative motif in the Pasemah plateau weren't discussed in the present research in relation to the shapes and postures, and thus the only one discussed here was megalithic statues. Painting, relief, and decorative motif were still elements found in megalithic artifacts (e.g., Stone Grave, Menhir, or Statue), not separated as complete artifacts like megalithic statues.

\subsection{Shapes of Megalithic Statues in Pasemah}

Based on the results of field study on the sites researched in Pasemah plateau, it proved that the megalithic artifacts of statue type were of the largest amount compared to other megalithic artifacts with their characteristic media being monolithic andesitic rocks. According to the shapes and images of the ancestors dedicated for the interest of worship and visualized in Pasemah megalithic statues, they can be grouped into two categories, namely: Firstly, Pasemah megalithic statues portraying one image or a single figure may be in a form of human figure or just an animal; secondly, Pasemah megalithic statues portraying more than one images or multiple figures, may be in forms of either human and human or human and animal, while animal with animal was not found in Pasemah. It indicates that Pasemah people then strongly upheld a concept of harmonious life with nature. 


\section{A. Erwan Suryanegara et al.}

\subsection{Postures of Megalithic Statues in Pasemah}

Furthermore, in fact, the postures of Pasemah statues show that Pasemah megalithic statues portraying human figures in particular are always in upright position (rigidly standing), or their legs incline to be folded forward so that their body lean forward indicating that the figure is moving (dynamical) or doing an activity. There are also statues whose legs are folded in a sitting position with one knee bent and folded back to one side. The results of field study were also proved as in agreement with that of library study, which were the results of previous researches on ancient artifacts in Pasemah.

The positions or postures of heads as the direction of viewing or eyes of Pasemah statues show that though some Pasemah megalithic statues had lost their head but, from the statues whose heads were still intact when the survey was conducted, it turned out that the direction of viewing of megalithic human statues inclined not to look down but rather look up, indicating optimistic attitudes or postures, except for statues in the site of Tebat Sibentur, whose face was sunk into soil so that it could be identified precisely.

Table2. Example of some Shapes and Postures of Pasemah Statues

\begin{tabular}{|c|c|c|c|}
\hline No. & Site & Statues' Shape and Posture & Statue Photograph \\
\hline \multirow[t]{2}{*}{1.} & \multirow[t]{2}{*}{$\begin{array}{l}\text { Tinggi } \\
\text { Hari III, Lahat }\end{array}$} & $\begin{array}{l}\text { Human and a water buffalo } \\
\text { A human is holding a water } \\
\text { buffalo, while looking up }\end{array}$ & \\
\hline & & $\begin{array}{l}\text { Human and a Tiger ( 'Imam' } \\
\text { Statue) } \\
\text { A human wearing a veil is } \\
\text { holding a tiger, while looking } \\
\text { up }\end{array}$ & \\
\hline 2. & $\begin{array}{l}\text { Pagaralam Pagun, } \\
\text { Lahat }\end{array}$ & $\begin{array}{l}\text { Tigers are copulating while } \\
\text { holding a child (human) } \\
\text { The child was gripping and } \\
\text { not being held by the tigers }\end{array}$ & \\
\hline \multirow[t]{2}{*}{3.} & \multirow[t]{2}{*}{ Geramat, Lahat } & $\begin{array}{l}\text { Human riding a water buffalo } \\
\text { A human riding a water } \\
\text { buffalo, in a posture of } \\
\text { accelerating the water buffalo }\end{array}$ & \\
\hline & & $\begin{array}{l}\text { Water Buffalo (single) } \\
\text { A water buffalo is standing, } \\
\text { tail being folded to its back } \\
\text { (in a leaning, nearly tumbling } \\
\text { position) }\end{array}$ & 8 \\
\hline
\end{tabular}




\begin{tabular}{|c|c|c|c|}
\hline 4. & $\begin{array}{l}\text { No longer in-situ } \\
\text { (collection } \\
\text { Balaputra of } \\
\text { Museum, Palembang) } \\
\text { originated r from } \\
\text { Kotaraya } \\
\text { Lahat }\end{array}$ & $\begin{array}{l}\text { Human riding an elephant } \\
\text { A man in robe is riding an } \\
\text { elephant while bringing a } \\
\text { nekara and carrying a sword }\end{array}$ & 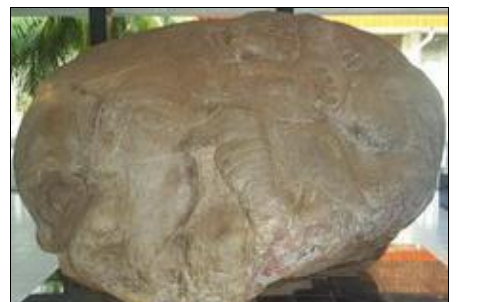 \\
\hline 5. & $\begin{array}{l}\text { Belumai } \\
\text { Pagaralam }\end{array}$ & $\begin{array}{l}\text { Human (single) } \\
\text { A man is bring a nekara and } \\
\text { carrying on a circle-shaped } \\
\text { object, his face being turning } \\
\text { left }\end{array}$ & \\
\hline 6. & $\begin{array}{l}\text { Tegur } \\
\text { Pagaralam }\end{array}$ & $\begin{array}{l}4 \text { Persons and } 4 \text { Elephants } \\
4 \text { persons are riding } 4 \\
\text { elephants while bring an } \\
\text { object (in different movement } \\
\text { and postures) }\end{array}$ & it \\
\hline
\end{tabular}

(The data is the Results of Survey by the researcher, August 2005 - February2006).

Observing closely each site surveyed, it turned out that in Pasemah statues there was never visually a repetition in shape, size, and posture, unlike in totems (menhir statues) that incline to have some similarities as described by Haris Sukendar (1983). As an evidence, the four statues at Tegur Wangi Pagaralam, though close to one another by a distance of no longer than one meter, their shapes, sizes, movements, expressions, and postures differ from one another. Their similarity visually is only in the carved element or structure of the object, namely, a human bringing something, as shown on Fig. 10 below:

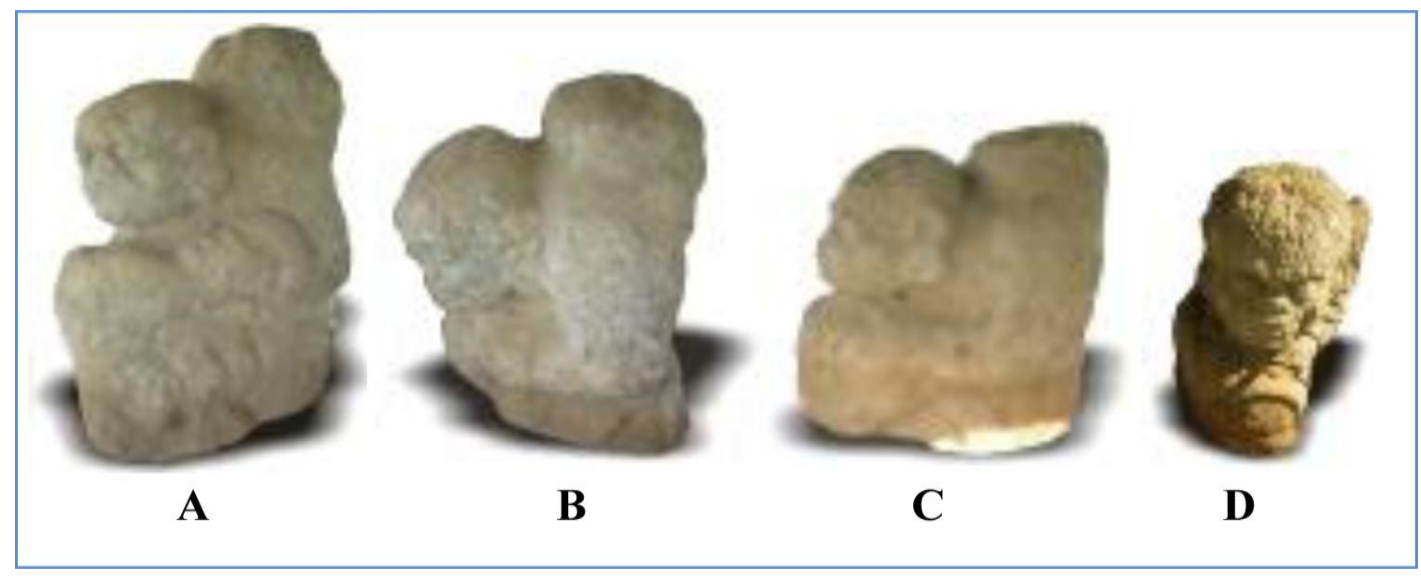

Fig10. Four elephant-riding human statues bringing an object, at site of Tegur Wangi.

Source: The Writer, 2005/2006

Dissimilarities of the four statues above are also seen in the diversity of the shapes and postures (visually) of Pasemah statues in other sites. The writer inferred it as a freedom of expression in working, both in Lahat Regency and Pagaralam Municipality, as can be found at the following sites: Tanjung Telang: A Human and an Elephant Hug One Another, High Slope: A Human(whose head has been lost) and a Snake, Blumai III: A Human Brings Nekara, Muara Danau: A Human Sits with a Wild Boar (Fig. 11: upper part from left to right), Tinggi Hari I: A Creature Holds Two Persons, Tinggi Hari II: A Mother with Her Child, and Tinggi Hari III: A Human Wears a Veil While Holding a Tiger (local people call it Patung Imam), Tanjung Ara, A Human with A Snake (Fig. 11: bottom part from left to right). 


\section{A. Erwan Suryanegara et al.}

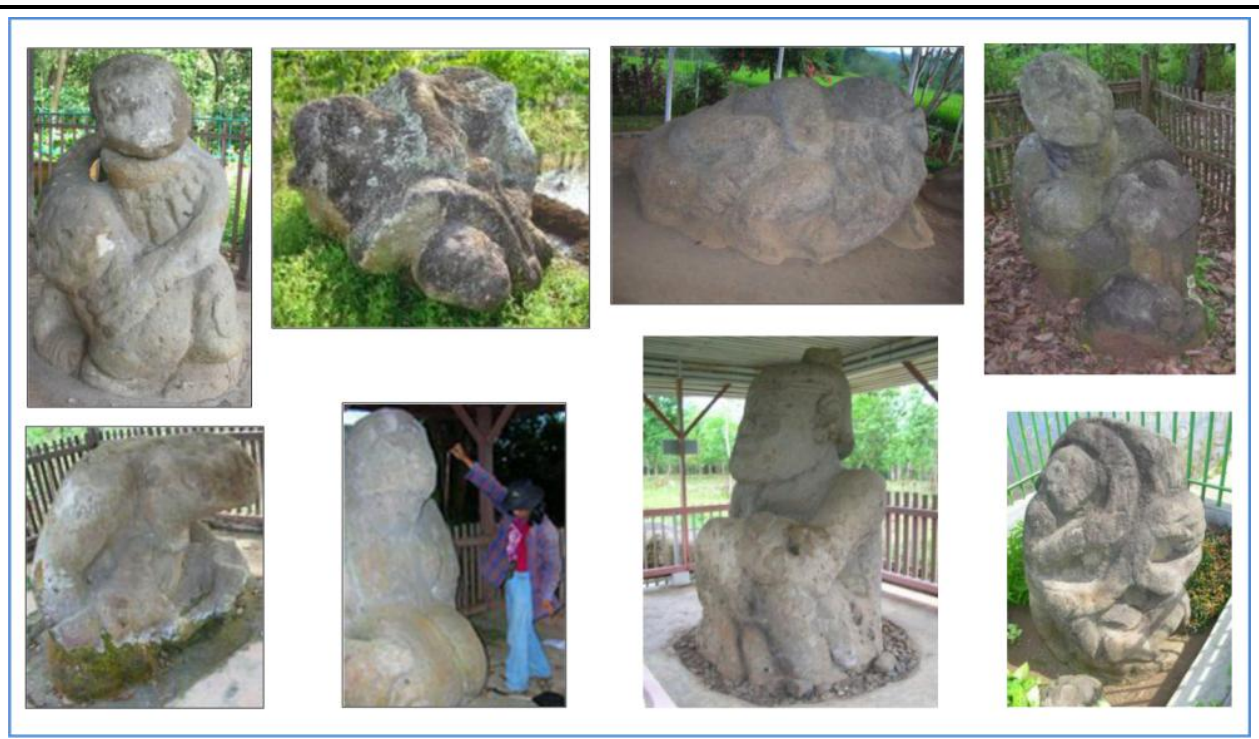

Fig11. Statues in several sites of Pasemah.

Source: The Writer, 2005/2006

As described above related to Pasemah visual works, besides from megalithic statues there are also other visual works such as reliefs, paintings, and decorative motifs, and thus the writer designated the multiple-shape Pasemah visual works as Pasemah fine arts. Unlike the statues, the paintings, reliefs, and decorative motifs in Pasemah are still parts of megalithic artifacts (not yet standing alone completely), such as paintings on the walls of Kubur Batu, reliefs in Menhir, and decorative motifs on both Statue and Menhir.

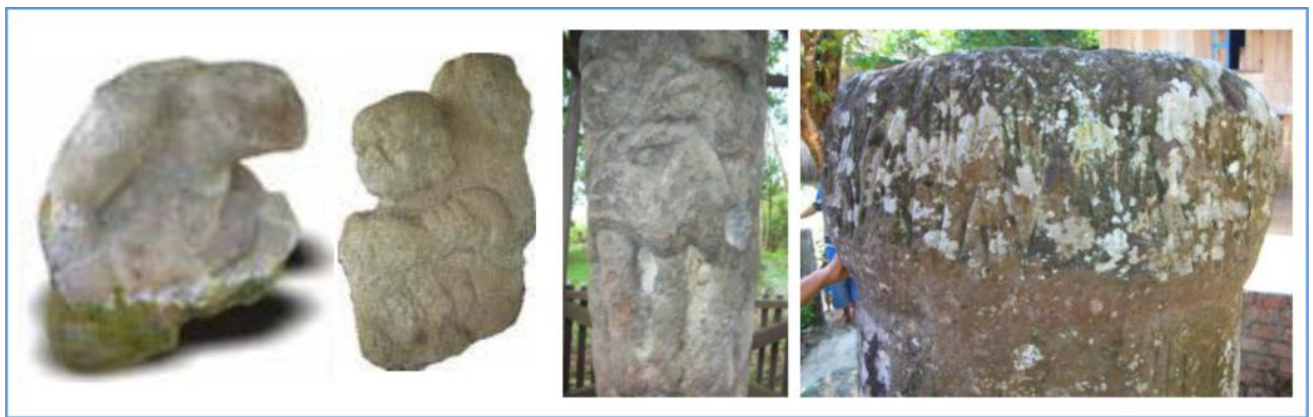

Fig12. Two statues, relief on Menhir, and tumpal decorative motifs on Menhir, Pasemah.

Source: The Writer, 2005/2006

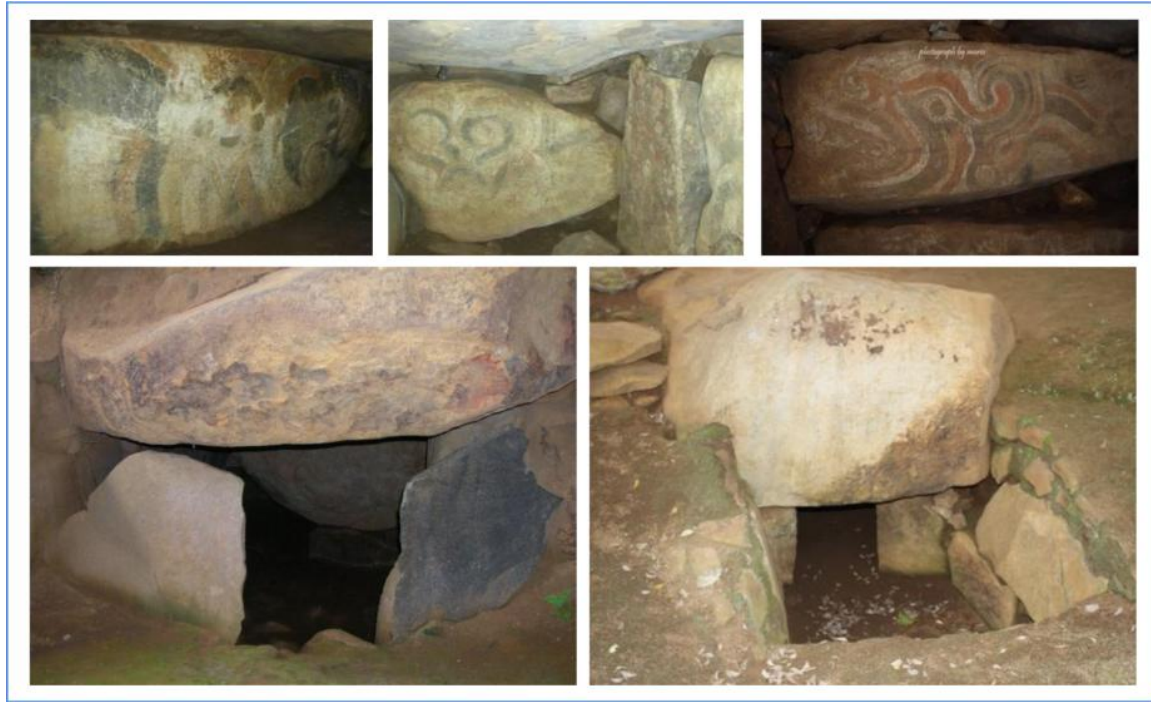

Fig13. Paintings on the walls of Kubur Batu (Stone Tombs), and two Kubur Batu Pasemah.

Source: The Writer, 2005/2006 
The visual works are called Pasemah visual artsgiven that the existence and diversity of the visual works' images as exemplified by Figs. 12 and 13, be they statues, paintings, reliefs, and decorative motifs, were in a time period of the development of civilization in Pasemah which is said as the era of Nusantara megalithic tradition.

\section{Conclusion}

The existence of Pasemah visual artsin the early times of the development of visual artsin Nusantara should be surfaced, given that the concept of art creation in the time didn't recognize esthetics as patronized in Europe. Based on the preceding discussion, it could be concluded as follows:

1. Pasemah's visual artsencompass a long time period of the developmental history of Nusantara's fine arts, which were the origin of visual arts(statue, painting, relief, and decorative motif) in Nusantara before the emergence of Bali's and Indonesia's fine arts.

2. The shapes of Pasemah megalithic statues: Firstly, portray a single shape or figure, may be a human figure or just an animal; Secondly, Pasemah megalithic statue portraying more than one shapes or figures, either human or human and animal. There is no object of animal and animal in Pasemah. This indicates that Pasemah humans firmly pursue a concept of living harmoniously with nature.

3. The postures of Pasemah statues that portray human figures in particular are always in postures that don't stand uprightly like statue, but rather the positions of their feet are inclined to be folded forward and thus the position of their body leans forward, portraying that either the figure is moving (dynamic) or doing an activity. There is also a statue in Pasemah with feet folded in a sitting position with one knee bent and folded back to one side.

4. The position or posture of head as the direction of viewing of Pasemah statue's face and eyes doesn't look down but rather look up, indicating optimistic attitudes.

5. They were mystical people, but they had showed a decorative motivation as shown at a menhir in Karang Dalam. The triangle shape, understood as one of the ancient symbols we called tumpal, has been carved at the upper side of menhir and carved repetitively, impressing that it played a role as a decoration (decorative motif) at the menhir.

6. The diversity of shapes and postures (visual) of Pasemah statues then was the initial time period of a freedom of expression in visual artsin Nusantara.

\section{REFERENCES}

Ayu Kusumawati, Haris Sukendar (2003). Pustaka Wisata Budaya Megalitik Bumi Pasemah. Jakarta: Departemen Pendidikan Nasional.

Bagyo Prasetyo (2015). Megalitik: Fenomena yang berkembang di Indonesia. Badan Penelitian dan Pengembangan Pusat Penelitian Arkeologi Nasional. Yoyakarta: Galangpress.

Bagyo Prasetyo, Nurhadi Rangkuti (2015). Pernak-Pernik Megalitik Nusantara. Badan Penelitian dan Pengembangan Pusat Penelitian Arkeologi Nasional. Yoyakarta: Galangpress.

Bagyo Prasetyo, Dwi Yani Yuniawati (2004). Religi pada Masyarakat Prasejarah di Indonesia. Jakarta: Departemen Kebudayaan dan Pariwisata.

Bambang Sugiyanto (2000). Hubungan Manusia dan Binatang pada Budaya Megalitik Pasemah (Tinjauan atas Arca Megalitik dan Lukisan Dinding Kubur). Jurnal Arkeologi Siddhayatra, Vol. 5 No. 2. Palembang: Balai Arkeologi

Budi Wiyana (1996). Survei Situs-situs Megalitik di Kabupaten Lahat Provinsi Sumatra Selatan. Palembang: Balai Arkeologi.

Erwan Suryanegara A (2006). Artefak Purba dari Pasemah: Analisa Ungkap Rupa Patung Megalitik di Pasemah. Program Studi Magister Seni Rupa. Bandung: Institut Teknologi Bandung.

Franz Dahler (2011). Asal dan Tujuan Manusia. Terjemahan Franz Magnis Suseno Yogyakarta: Penerbit Kanisius.

Hoop, van der A.N.J.Th.A.Th (1932). Remains in South-Sumatra. Netherland: Translated by William Shirlaw, Printed and Published by W.J. Thieme \& Cie Zutphen.

Imam Suhardiman, Drs (2001). Atlas Indonesia dan Dunia. Surabaya: Cetakan ke-7, CV. Indo Prima Sarana. 


\section{A. Erwan Suryanegara et al.}

Ketut Wiradnyana (2015). Perkembangan Religi Prasejarah: Tradisi Masyarakat Gayo. Jurnal Arkeologi Amerta, Vol. 33 No. 1. Jakarta: Pusat Arkeologi Nasional.

Kritantina Indriastuti (2011). Gaya dan Nilai-Nilai Pemahat Batu pada Arca Megalitik di Situs Rindu Hati Kecamatan Gumay Ulu, Kaupaten Lahat, Provinsi Sumatra Selatan. Jurnal Arkeologi Siddhayatra, Vol. 16 No. 1. Palembang: Balai Arkeologi

Kritantina Indriastuti (2013). Bentuk dan Karakter Megalitik di Kecamatan Dempo Utara, Kota Pagaralam, Prov. Sumatra Selatan. Jurnal Arkeologi Siddhayatra, Vol. 18 No. 2. Palembang: Balai Arkeologi

Pals, Daniel L (1995). Seven Theories of Religion. Terjemahan oleh Inyiak Ridwan Muzir, Syukri M (2012). Yogyakarta: Penerbit: IRCiSoD

Rachmat Subagya (1981). Agama Asli Indonesia. Jakarta: Penerbit Sinar Harapan dan Yayasan Cipta Loka Caraka.

R. Soekmono (1976). Pengantar Sejarah Kebudayaan Indonesia. Jakarta: Yayasan Kanisius.

Samsudin, Kritantina Indriastuti, Rapanie (2013). Peninggalan Sejarah dan Purbakala Sumatra Selatan. Palembang: Dinas Kebudayaan dan Pariwisata Provinsi Sumatra Selatan.

\section{AUTHOR's BIOGRAPHY}

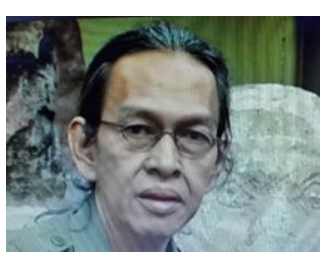

A. Erwan Suryanegara Lives in Palembang, Sumatra Selatan, Home Address: Jln. Anggda No. 6 RT. 08 RW. 02 Kalidoni, Palembang - 30118. During study, lives in Bandung, West Java, Home Address: Jln. Babakan Ciamis No. 78B RT. 01 RW. 03 Kelurahan Babakan Ciamis, Kecamatan Sumur Bandung, Bandung - 40117, Contact person: +62 81368829559. Independent Researcher, a Cultural Worker and as a Lecturer at IGM University, Palembang. Also, the author of "Kerajaan Sriwijaya" and "Ragam Hias di Sumatra Selatan." Producer as well as the Initiator and Director of the Documentary Films of "Napak Tilas Sriwijaya di Bumi Nusantara" and "Ragam Hias di Sumatra Selatan." Right now completing in Doctoral Programme - Faculty of Art and Design, ITB (Bandung Institut of Technology) 